\title{
MODIFICATIONS TO THE THEORY OF INTRAGLACIAL WATERWAYS FOR THE CASE OF SUBGLACIAL ONES
}

\author{
By LOUIS LLIBOUTRY \\ (Laboratoire de Glaciologie et Géophysique de l'Environnement, 2 rue Très-Cloitres, 38031 \\ Grenoble Cédex, France)
}

\begin{abstract}
It is argued that in temperate mountain glaciers, waterways are subglacial. It is shown that the theory of Spring and Hutter (1981) for intraglacial flooded conduits leads to an equation for the grade line which differs from Röthlisberger's (1972) only by negligible terms, and a slight modification of the exponent of the discharge. For a subglacial flooded waterway two important processes should instead be introduced: the enhancement of plastic deformation on the up-stream side of bumps, and the heat afforded by ground water (which in winter accounts for most of the discharge). The theory modified in this way explains why Röthlisberger had to adopt an unrealistic value for the rheological parameter of ice. It leads to the conclusion that in areas which are not overdeepened, most of the year subglacial waterways should remain not flooded and at atmospheric pressure. The case of overdeepening is examined. Finally the implications of this new model for glacier sliding theory are demonstrated.
\end{abstract}

RÉSUMÉ. Modifications à la théorie des torrents intra-glaciaires dans le cas où ils sont sous-glaciaires. On défend l'idée que, dans les glaciers de montagne tempérés, les voies d'eau sont sous-glaciaires. On montre que la théorie de Spring et Hutter (1981) pour des conduits noyés intra-glaciaires conduit à une équation pour la ligne piézométrique qui ne diffëre de celle de Röthlisberger (1972) que par des termes négligeables, et une légère modification de l'exposant du débit. Pour un conduit noyé sous-glaciaire il faut plutôt introduire deux processus importants: l'accroissement de la déformation plastique sur les côtés amont des bosses, et la chaleur apportée par l'eau des sources (qui en hiver rend compte de la plus grande partie du débit). La théorie ainsi modifiée explique pourquoi Röthlisberger dut adopter une valeur non réaliste pour le paramètre rhéologique de la glace. Elle conduit à la conclusion que dans les zones non surcreusées, la plus grande partie de l'année, les conduits sous-glaciaires doivent rester non noyés et à la pression atmosphérique. Le cas des surcreusements est examiné. Pour conclure on expose l'incidence de ce nouveau modèle sur la théorie du glissement des glaciers.

ZuSAMMENFASSUNG. Änderungen zur Theorie der intraglazialen Wasserführung für der subglazialen Fall. Es wird erörtert, dass die Wasserführung in temperierten Gletschern subglazial verläuft. Es lässt sich zeigen, dass die Theorie von Spring und Hutter (1981) für intraglaziale, volle Kanäle zu einer Gleichung für die Gefällslinie führt, die sich von der von Röthlisberger (1972) nur um vernachlässigbare Grössen und eine leichte Änderung des Abflussexponenten unterscheidet. Statt dessen sollten für eine subglaziale, angefüllte Wasserführung zwei wichtige Vorgänge berücksichtigt werden: die Zunahme der plastischen Deformation an der stromaufwärts gelegenen Seite von Buckeln und die durch Grundwasser zugeführte Wärme (die im Winter den Grossteil des Abflusses bewirkt). Die so modifizierte Theorie erklärt, warum Röthlisberger einen unrealistischen Wert für den rheologischen Parameter von Eis anzunehmen hatte. Es folgt daraus, dass in nicht übertieften Gebieten über einen Grossteil des Jahres die subglazialen Wasserführungen nicht voll und auf dem Druckniveau der Atmoshäre bleiben. Der Fall von Übertiefungen wird geprüft. Schliesslich wird der Einfluss dieses neuen Modells auf die Theorie des Gletschergleitens dargelegt.

\section{INTRODUCTION}

The variation in cross-section of subglacial or intraglacial waterways pre-existing in a glacier has been examined in the context of the outburst of ice-dammed lakes. At the symposium on the hydrology of glaciers held at Cambridge in 1969, the Manning formula (which gives the discharge in a conduit for turbulent flow) and Nye's calculation of the rate of closure of the conduit by plastic deformation were introduced by Mathews (1973) and Röthlisberger (1972). While the first of these authors stated that this plastic deformation is too small to explain field 
evidence and assumed that collapse of large blocks of ice (an observed fact) should be an important factor, the second adjusted the value of the ice flow-law parameter to account for the case of the emptying of Gornersee. His plastic closing rate is at least four times larger than the field and experimental values. On the other hand Röthlisberger's theory is more complete: the variation of melting point with pressure is taken into account, and the steady-state case examined in full.

Later on, Nye (1976) developed a theory for transient siuations. He assumes that ice is permeable, a very controversial statement (Lliboutry, 1971) which is to be discussed in two companion papers by D. Hantz and by M. Vallon and others. It appears that, at depth, glacier ice has a very small evolutive permeability, insufficient to modify significantly the discharge during the melting season or during a jökulhlaup.

Recently, Spring and Hutter (1981) have modified Röthlisberger's theory in two ways: first by using instead of Manning's empirical relation one which is better grounded, secondly, by introducing some terms which, except maybe in the case of heavy discharge in early summer and jökulhlaups, will be shown to be completely negligible. Only the case of an intraglacial conduit was considered by these authors, whereas field evidence shows that in temperate glaciers waterways are subglacial. This point will be argued. As a consequence, two other factors should be taken into account: ground water at temperatures above the melting point which enters directly into the waterway at many places, and ice-bedrock separation.

The author's modifications of the theory have important consequences in two problems: the design of subglacial catchments for hydro-electric plants, and the sliding law of temperate glaciers, which will be examined next.

\section{THE THEORY FOR AN INTRAGLACIAL DROWNED CHANNEL IN THE STEADY STATE}

Following Röthlisberger, and contrary to the usage of Spring and Hutter, $s$ will denote the distance along the waterway up-stream. Let $Z_{\mathrm{k}}$ be its altitude, $H_{\mathrm{i}}$ the altitude of the glacier surface, $H$ the altitude of the hydraulic grade line (the same notation as in Spring and Hutter, 1981), $S$ the cross-sectional area, and $R$ the hydraulic radius. We define $\beta$ as does Röthlisberger:

$$
\sin \beta=\mathrm{d} Z_{\mathrm{k}} / \mathrm{d} s \text {. }
$$

Let $\rho_{\mathrm{w}}$ and $\rho_{\mathrm{i}}$ be the respective densities of water and ice, $p_{\mathrm{w}}=H-Z_{\mathrm{k}}$ the water pressure, $p_{\mathrm{i}}=\left(H_{\mathrm{i}}-Z_{\mathrm{k}}\right) \rho_{\mathrm{i}} / \rho_{\mathrm{w}}$ the ice pressure, in metres of water, and $\Delta H=p_{\mathrm{i}}-p_{\mathrm{w}}$.

Only smoothed values of $S, R, \sin \beta$, and $H_{\mathrm{i}}$ are considered. Local fluctuations, which may be important when the waterway runs between ice and rock, will be considered later on.

Röthlisberger uses the Gauckler-Manning-Strickler empirical relation between the discharge $Q$ and the piezometric gradient $\mathrm{d} H / \mathrm{d} s$ in turbulent steady flows:

$$
\frac{\mathrm{d} H}{\mathrm{~d} s}=k^{-2}\left(\frac{S}{R^{2}}\right)^{2 / 3} \frac{Q^{2}}{S^{8 / 3}}
$$

where $k$ is Manning's coefficient, and $S / R^{2}$, for a flooded intraglacial waterway, depends on the shape of the cross-section, and not on its area $S$.

Spring and Hutter instead introduce a turbulent drag $\tau_{0}$, given by the semi-empirical relation

$$
\tau_{0}=\frac{f_{\mathrm{R}} \rho_{\mathrm{w}}}{8}\left(\frac{Q}{S}\right)^{2}
$$


where $f_{\mathrm{R}}=0.25$ is a constant. The balance of momentum leads then to their second equation (2.8) and second equation (2.11) (where the insignificant quantity $m v$ has been dropped):

$$
\frac{\partial H}{\partial s}+\frac{1}{2 g} \frac{\partial\left(v^{2}\right)}{\partial s}=X_{\mathrm{E}} \frac{Q^{2}}{S^{5 / 2}}
$$

where $v=Q / S$ is the mean velocity, and $X_{\mathrm{E}}=\sqrt{\pi} f_{\mathrm{R}} /(4 g)$. Now $\mathrm{d} H / \mathrm{d} s$ should be of the same order of magnitude as the glacier slope, that is 0.1 , while $v$ in an alpine glacier is of the order of $3 \mathrm{~m} \mathrm{~s}^{-1}$ in summer, and less in winter. The second term on the 1.h.s. (acceleration term) should then be of the order of $10^{-4}$ at most, and can be neglected in our problem. For almost steady flows, $\partial H / \partial s \simeq \mathrm{d} H / \mathrm{d} s$. The only difference between Equations (4) and (2) is then that the power of $S$ has become $5 / 2$ instead of $8 / 3$.

The flow law of ice is taken, with standard notation, as

$$
\dot{\varepsilon}_{i j}=\tau^{n-1} \tau_{i j}^{\prime} / A^{n} .
$$

The balance of melting and closure by plasticity affords then, in the steady state, $m$ being the mass of ice which melts per unit length and unit time, and $g$ denoting the gravity:

$$
\frac{m}{\rho_{\mathrm{i}}}=2 S\left(\frac{\rho_{\mathrm{w}} g}{n A}\right)^{n}(\Delta H)^{n} \text {. }
$$

There is a thermal boundary layer at the ice wall, through which the temperature jumps by $\Delta T$. Let us write the energy balance, neglecting the heat per unit mass $c \Delta T$ needed to warm melting water to the mean temperature $T$ in addition to the latent heat $L$ needed to melt it, and neglecting also (as commonly done in hydraulics) the eddy kinetic energy:

$$
\frac{\mathrm{d} H}{\mathrm{~d} s} \rho_{\mathrm{w}} g Q=m L-\rho_{\mathrm{w}} c Q \frac{\mathrm{d} T}{\mathrm{~d} s} .
$$

The lowering of the melting point per unit of pressure being $c_{t}$, in degrees Celsius:

$$
T=\Delta T-c_{t} \rho_{\mathrm{w}} g\left(H-Z_{\mathrm{k}}\right) .
$$

As pointed out by Harrison (1972), $c_{t}=0.0098 \mathrm{deg}^{\mathrm{bar}}{ }^{-1}$ (and not 0.0074 as stated by Röthlisberger) because water should be air-saturated. Then the dimensionless quantity $c_{t} c \rho_{\mathrm{w}}=0.413$ and Equation (7) becomes

$$
\frac{m}{\rho_{\mathrm{w}}}=\frac{g Q}{L}\left[\frac{\mathrm{d} H}{\mathrm{~d} s}+\frac{c}{g} \frac{\mathrm{d} \Delta T}{\mathrm{~d} s}-0.413\left(\frac{\mathrm{d} H}{\mathrm{~d} s}-\sin \beta\right)\right] .
$$

Assuming that in the steady state the thermal jump $\Delta T$ is either negligible or independent of $s$, it follows from Equations (4), (6), and (9) that

$$
\left[0.587 \frac{\mathrm{d} H}{\mathrm{~d} s}+0.413 \sin \beta\right]\left[\frac{\mathrm{d} H}{\mathrm{~d} s}\right]^{2 / 5}=\frac{2 L \rho_{\mathrm{i}}}{\rho_{\mathrm{w}} g} X_{\mathrm{E}}^{2 / 5}\left(\frac{\rho_{\mathrm{w}} g}{n A}\right)^{n} Q^{-1 / 5} \Delta H^{n}
$$

which may be written in a dimensionless form as

$$
\left(\frac{\mathrm{d} H}{\mathrm{~d} s}+0.704 \sin \beta\right)\left(\frac{\mathrm{d} H}{\mathrm{~d} s}\right)^{2 / 5}=\left(\frac{Q_{0}}{Q}\right)^{1 / 5}\left(\frac{\Delta H}{H_{0}}\right)^{n} .
$$


Numerically, $Q_{0}=1 \mathrm{~m}^{3} \mathrm{~s}^{-1}$ will be adopted. Then,

$$
H_{0}=3 A\left(\frac{0.587}{2 L \rho_{\mathrm{i}}}\right)^{1 / 3}\left(\rho_{\mathrm{w}} g\right)^{-2 / 3}\left(\frac{4 g}{\sqrt{\pi} f_{\mathrm{R}}}\right)^{2 / 15} Q_{0}^{1 / 15} .
$$

Let us check that $c \partial \Delta T / \partial s$ is negligible, by using Spring and Hutter's calculations. To relate $m$ and $\Delta T$, they use an empirical relationship given by McAdams for heat transfer in a cylindrical pipe. The result is

$$
\frac{m}{\rho_{\mathrm{w}}}=X_{Q}\left(\frac{Q^{2}}{S}\right)^{2 / 5} \Delta T
$$

where

$$
X_{Q}=1.493 \times 10^{-5} \mathrm{deg} \mathrm{m}^{2 / 5} \mathrm{~s}^{-1 / 5}
$$

with Spring and Hutter's numerical values (in particular $n=3$ ). (There are two misprints in their fifth equation (2.8)). Substituting for $m$ from Equation (6) we get

$$
\Delta T=\frac{1}{X_{\mathrm{S}}} \frac{\rho_{\mathrm{i}}}{\rho_{\mathrm{w}}} \frac{S^{7 / 5}}{Q^{4 / 5}} \Delta H^{n}
$$

where $X_{\mathrm{S}}=\left(X_{Q} / 2\right)\left(n A / \rho_{\mathrm{w}} g\right)^{n}$ is a new parameter introduced by Spring and Hutter. (The exponent $7 / 5$ has been dropped in their first equation 2.12, and the numerical value of $X_{\mathrm{S}}$ in their table 2 should read $4.16 \times 10^{7} \mathrm{~m}^{17 / 5} \mathrm{~s}^{4 / 5} \mathrm{deg}^{-1}$ instead of $2.95 \times 10^{5} \mathrm{~m}^{17 / 7} \mathrm{~s}^{4 / 7} \mathrm{deg}^{-5 / 7}$ ). Substituting $S$ from Equation (4) (where the acceleration term is neglected), we get a relation with a new coefficient $X_{\mathrm{T}}$, not considered by these authors:

$$
\begin{aligned}
& \Delta T=X_{\mathrm{T}} Q^{8 / 25} \Delta H^{n}\left(\frac{\mathrm{d} H}{\mathrm{~d} s}\right)^{-14 / 25}, \\
& X_{\mathrm{T}}=X_{\mathrm{E}}^{14 / 25} X_{\mathrm{s}}^{-1} \rho_{\mathrm{i}} / \rho_{\mathrm{w}}=1.76 \times 10^{-9} \mathrm{deg} \mathrm{m} \mathrm{m}^{-99 / 25} \mathrm{~s}^{8 / 25} \text {. }
\end{aligned}
$$

Orders of magnitude are: $\mathrm{d} H / \mathrm{d} s \approx 0.1 ; Q \approx 1 \mathrm{~m}^{3} \mathrm{~s}^{-1} ; \Delta H \approx 100 \mathrm{~m} ;$ and then $\Delta T \approx 0.007 \mathrm{deg}$. The heat capacity of the thermal boundary layer $(c \Delta T)$ is completely negligible, and Röthlisberger's (1972) theory was sound. The only changes to be made to his equation (20) in the case of an intraglacial flooded channel, are to replace 0.316 by 0.413 and $Q^{-1 / 4}$ by $Q^{-1 / 5}$.

\section{VAlue of THE RHEOlogical PARAMEter $A$}

Rheological parameters of temperate ice are satisfactorily well known today thanks to the careful experimental work by Duval (1977[a], [b]). For the range of stresses which is pertinent here, $n=3$. For permanent tertiary creep, $A$ varies according to the water content or, when this content is not measurable, to the temperature (which becomes then definitely lower than the melting point for pure ice). On Figure 1 Duval's experimental values for $B$ are plotted versus enthalpy $G$ given by

$$
G=0.492 T+0.80 w \mathrm{cal} / \mathrm{g}
$$

where $T$ is the temperature relative to the melting point for pure ice and $w$ the water content in 


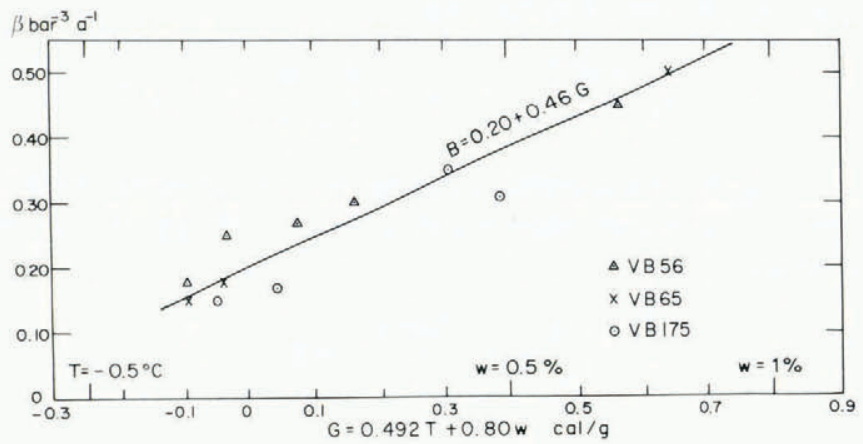

Fig. 1. Flow law parameter B (defined in the text) for tertiary creep of temperate glacier ice, according to Duval's laboratory measurements.

per cent. The following good correlation is found between Duval's parameter $B$ and $G$ :

$$
\begin{gathered}
B=2 A^{-3}=0.20+0.46 G=0.20+0.226 T+0.368 w b^{-3} a^{-1} \\
\left(T \geqslant-0.2^{\circ} \mathrm{C}, w \leqslant 0.8 \%\right) .
\end{gathered}
$$

(Incidentally, if the influence of temperature were analysed by an Arrhenius law, an activation energy of $700 \mathrm{~kJ} / \mathrm{mol}$, one order of magnitude larger than for cold ice, would be found.)

We may compare this value with the one deduced by Haefeli (1963) from the closure of a tunnel in Z'Muttgletscher, $k_{1}=B=0.25 \mathrm{bar}^{-3} \mathrm{a}^{-1}$. From the same tunnel and another one in Vesl-Skautbreen, Norway, Röthlisberger (1972) finds $B=0.32 \mathrm{bar}^{-3} \mathrm{a}^{-1}$, the value which is adopted by Spring and Hutter. These values correspond, according to Equation (17), to $w=0.14$ and $0.33 \%$ respectively, which are plausible values near an empty tunnel.

Numerous measurements of water content in ice cores from glacier d'Argentière (Vallon and others, to be published) have shown that in blue ice, as found near the bottom, the water content fluctuates at random between 0.60 and $0.95 \%$, the most common value being around $0.72 \%$. This last value will be adopted. It leads to

$$
\begin{aligned}
& B=0.465 \mathrm{bar}^{-3} \mathrm{a}^{-1} \\
& A=(2 / B)^{1 / 3}=5.14 \times 10^{7} \mathrm{~Pa} \mathrm{~s}^{-1 / 3}
\end{aligned}
$$

and then Equation (12) gives

$$
H_{0}=607 \mathrm{~m} \text {. }
$$

In order to fit the data of Gornersee, Röthlisberger was obliged to adopt $B=2.00 \mathrm{bar}^{-3} \mathrm{a}^{-1}$, an incredibly high value: it would lead, according to Equation (17), to $w=4.9 \%$, a water content never observed. Thus some important point was missed in his model: either the plastic closure rate does not have its standard value, or the melting rate at the walls of the conduit is less than calculated.

It has been suggested by A. Bezinge (verbal communication) that the discrepancy comes from the fact that the conduit which drains Gornersee makes its path between two ice streams, one coming from the upper Gornergletscher and the other from Grenzgletscher, and that the 
latter is cold. According to Röthlisberger its temperature is -2 to $-3{ }^{\circ} \mathrm{C}$. It is easily shown that the cold brought by this cold ice is insignificant.

To obtain a very rough order of magnitude, let us assume a steady discharge, $Q=10 \mathrm{~m}^{3} \mathrm{~s}^{-1}$ (whence, for a circular flooded waterway, the radius $r_{0}=1.5 \mathrm{~m}$ ). Although the warming extends progressively into Grenzgletscher as it flows down, let us assume a constant extension to a distance $r_{1}=50 \mathrm{~m}$ (the distance reached in about one century).

For a pipe of circular cross-section, inner radius $r_{0}$, outer radius $r_{1}$, thermal conductivity $K$, having its walls kept at $T_{0}$ and $T_{1}$ respectively, the heat loss per unit length and unit time is, in the steady state:

$$
q=2 \pi K\left(T_{0}-T_{1}\right) / \ln \left(r_{1} / r_{0}\right) .
$$

With a waterway near the bottom and cold ice on one side only, a quarter of this value should be adopted. With $K=2-2.3 \mathrm{~W} \mathrm{deg}^{-1} \mathrm{~m}^{-1}, T_{0}-T_{1}=2-3{ }^{\circ} \mathrm{C}$, the heat so lost over about $5 \mathrm{~km}$ is of the order of $10 \mathrm{~kW}$, while the Newtonian energy supplied when descending about $500 \mathrm{~m}$, is $50 \mathrm{MW}$.

So in this case there needs to be some process which enhances closure rates by plasticity. This comes from the waterway being subglacial, a point to argue first.

\section{IN GENERAL WATERWAYS ARE SUBGLACIAL}

Waterways within a glacier at large distance from the bed seem to exist only in Arctic cold glaciers, which are fed by superimposed ice. In such glaciers superficial streamlets often become imbedded within the ice at a shallow depth. In temperate glaciers, during the melting season, superficial streams end by pouring into crevasses, which become moulins when the crevasse shuts (Stenborg, 1973). Series of moulins from successive crevasses, the upper one only being active, are found on Mer de Glace between the ice stream coming from glacier du Tacul and the one coming from glacier de Leschaux, also on glacier d'Argentière in front of Refuge d'Argentière and between the main ice stream and the one coming from glacier des Améthystes. The limit between two ice streams remains a weak surface, where longitudinal crevasses start preferentially.

All this water pouring into moulins reaches the bed. As noted by Stenborg, the flooding of a moulin after heavy melting has never been observed. In the road tunnel below glacier du Géant (Mont Blanc Massif) isotopic measurements have shown that the large amount of water which flows out from rock joints comes directly from the glacier (Fontes and others, 1979). It must have reached the bed first. Incidentally, the water produced at the very ice-bed interface by geothermal heat, or by the melting-refreezing process of sliding (Lliboutry, 1979) is two orders of magnitude lower, and may be neglected. The same is true for water percolating through glacier ice (Lliboutry, 1971; Berner and others, [1978]).

How a water-filled crevasse can reach the bottom is an interesting problem. Glen (1954) suggested a slow deepening by plastic deformation, a process which was disproved by Stenborg (1973). In fact it is a problem of rupture, which involves the elastic properties of ice and which has been successfully investigated by Weertman (1973). Nevertheless his theory assumes that waterways at atmospheric pressure pre-exist at the bed. In our opinion fast sliding and ice-bedrock separation is a necessity. The crack propagates towards some subglacial cavity where water pressure is less than the main ice pressure at the bottom. Next, the water head forces a way along the glacier bed, and a conduit of appropriate size is created. 
All direct observations of subglacial waterways made in Switzerland have been summarized by Bezinge (unpublished).

\section{MODIFICATIONS OF THE THEORY FOR SUBGLACIAL WATERWAYS}

Let us assume now that the water flows along a V-shaped furrow of the bedrock of angle $\psi$ rad. At the scale of the conduit cross-section, perfect sliding of ice over the bedrock can be assumed. Then, since plastic closure impedes a hydrostatic state of stress at the abutments of the vault of ice, this vault must abut normally against the bedrock. Moreover the turbulent heat transfer in the water favours a rounded vault. Thus we may assume the cross-section of the flooded conduit to be a circular sector of radius $r$. Therefore, $S / R^{2}=2(2+\psi)^{2} / \psi$, which has a flat maximum for $\psi=2$, namely $S / R^{2}=16$. If Equation (2) were used, $\mathrm{d} H / \mathrm{d} s$ would be altered by a factor $(16 / 4 \pi)^{2 / 3}=1.175$. If we use instead Equation (3), and assume that the drag coefficient is the same for the water-polished bedrock as for ice, the coefficient $X_{\mathrm{E}}$ in Equation (4) does not change at all.

With this circular sector model the formula for plastic shrinking of a circular pipe remains valid. Therefore Equation (6) and lastly Equations (11) and (12) are not modified. Although it may be shown that $X_{\mathrm{Q}}$ and $X_{\mathrm{S}}$ are multiplied by $2^{-4 / 5} \psi /(\psi+2)$, and then, for given $S, Q$, and $\Delta H$, the thermal jump $\Delta T$ is larger, the thermal capacity of the thermal boundary layer can still be neglected in the steady state.

A more important change to be made is to consider the fluctuations of the cross-section area $S$ with distance $s$ at the minute scale. In a two-dimensional model, at the scale of the bedrock micro-relief, cavities are formed in the lee of some bumps, and the ratio of the length over which active ice is in contact with the bedrock to the whole length is $E<1$. If a sine profile having the controlling obstacle size is a valuable model, the resulting pressure $p_{\mathrm{i}}-p$ is enlarged by a factor $1 / E$ on the up-stream side of the bumps, and vanishes on the down-stream side (Lliboutry, 1979; $E$ is called $s$ in that paper). The closure rate is therefore enhanced by a factor $E^{-n}$ during a period of $E$ times the transit time, and is null during $(1-E)$ times the transit time. On average, the closure rate is multiplied by $E^{-2}$. To obtain the fourfold apparent increase of $B$ at Gornergletscher, it suffices to assume that $E=0.5$.

The reader will object that sliding is small, subglacial cavities not ubiquitous, and such a low value of the parameter $E$ in the sliding theory seems too low. But waterways avoid the places with over-pressures, the up-stream side of bumps. They turn away instead, and make their path along as many cavities as possible. The $E$ introduced here should be much smaller than the $E$ pertinent to sliding theory.

This enhancing process will be accounted for by putting on the r.h.s. of Equations (6), (10), and (11) a factor $\varphi$ equal to about 4 .

Another important improvement to the theory is to consider the input of water into the waterway. In the ablation area at least, lateral streamlets and more diffuse water sources percolating through lateral moraines, are an obvious fact. During winter the stream flowing from an alpine glacier does not vanish; at that season it can only come from subglacial springs. Thus the discharge $Q$ increases going down-stream, even if (as assumed here), no intraglacial or subglacial waterways with water at the cold equilibrium temperature meet the waterway we are considering. Let us smooth the variations of $Q$, and assume $\mathrm{d} Q / \mathrm{d} s$ to be everywhere finite and negative. 
Ground water is above the melting point, and its path between spring and the waterway at the ice-bedrock interface, must be too short to allow it to reach the melting point. Let $\theta$ be its temperature when it reaches the waterway relative to the melting temperature under the pressure existing there. Per unit time and unit length, the amount of heat so afforded is $-c \rho_{\mathrm{w}} \theta \mathrm{d} Q / \mathrm{d} s$ to be added to the l.h.s. of Equation (7). Equation (11) becomes then, for a subglacial waterway,

$$
\left[\frac{\mathrm{d} H}{\mathrm{~d} s}+0.704 \sin \beta-\frac{a \theta}{Q} \frac{\mathrm{d} Q}{\mathrm{~d} s}\right]\left[\frac{\mathrm{d} H}{\mathrm{~d} s}\right]^{2 / 5}=\left[\frac{Q_{0}}{Q}\right]^{1 / 5} \varphi\left[\frac{\Delta H}{H_{0}}\right]^{3}
$$

with

$$
a=\frac{c}{0.587 g}=733 \mathrm{~m} \mathrm{deg}^{-1} .
$$

During winter, when almost all of the water flowing in the subglacial conduit is ground water, for a valley glacier several kilometres long, $(1 / Q)(\mathrm{d} Q / \mathrm{d} s)$ should be of the order of $-10^{-3} \mathrm{~m}^{-1}$. Since $\theta$ is of the order of $1^{\circ} \mathrm{C}$, the last term so introduced into the first bracket of equation (20) is of the order of unity, one order of magnitude larger than the two other ones. It is only at the climax of the melting season that it should become negligible.

\section{IN GENERAL SUBGLACIAL WATERWAYS ARE NOT DROWNED}

When changes with time are not very fast and the conduit is flooded, Equation (20) holds more or less. It implies that $\mathrm{d} H / \mathrm{d} s=\mathrm{d} p_{\mathrm{w}} / \mathrm{d} s+\sin \beta$ is non-negative. Near the glacier terminus, $\Delta H / H_{0}$ is quite small, and then $\mathrm{d} H / \mathrm{d} s$ almost zero. In the normal case, $\sin \beta>0$, and then $\mathrm{d} p_{\mathrm{w}} / \mathrm{d} s<0$. Since at the very end $p_{\mathrm{w}}$ equals the atmospheric pressure, it cannot be so over a long distance. Afterwards, going up-stream, the conduit is not flooded until $\beta \approx 0$ or until an overdeepening ( $\sin \beta<0$ ) is found.

The picture which emerges is thus quite different from the one dealt with by hydrologists up to this date. A steady state during which plastic closure of the conduit balances melting of its walls does not exist. There are periods of high discharge during the melting season during which the conduit is flooded, the water pressure is high, and the conduit enlarges. In the remainder of the year the conduit shrinks progressively. This is the situation which has always been found when direct observations could be made (Bezinge, unpublished). In this case subglacial water which can afford enough energy to enlarge any pre-existing conduit, always flows, sooner or later, along the deepest part of the valley, as any stream would if the glacier did not exist.

\section{THE CASE OF OVERDEEPENING}

To study the case of overdeepening, we shall refer to that existing below glacier d'Argentière up-stream from the water catchment of Lognan (Hantz and Lliboutry, 1983). Going upstream ( $s$ increasing) over $400 \mathrm{~m}$, the bedrock lowers by $55 \mathrm{~m}(\sin \beta=-0.136)$, while the glacier surface rises by $70 \mathrm{~m}\left(\mathrm{~d} H_{\mathrm{i}} / \mathrm{d} s=0.176\right)$. The glacier thickness $H_{\mathrm{i}}-Z_{\mathrm{k}}$ increases more or less linearly from 100 to $225 \mathrm{~m}$. Since $(\theta / Q),(\mathrm{d} Q / \mathrm{d} s)$, and $\varphi$ are very poorly known, any numerical integration of Equation (20) would be illusory, and only orders of magnitude can be calculated.

At the down-stream end, $\Delta H=90 \mathrm{~m}$. Let us adopt $\varphi\left(\Delta H / H_{0}\right)^{n}=0.08 ;-(a \theta / Q)(\mathrm{d} Q / \mathrm{d} s)=1.0$ in winter time, and 0.1 in late summer; $Q=0.1 \mathrm{~m}^{3} \mathrm{~s}^{-1}$ in winter and $3 \mathrm{~m}^{3} \mathrm{~s}^{-1}$ in late summer. 
Equation (20) then gives

in winter:

$$
\begin{gathered}
\left(\frac{\mathrm{d} H}{\mathrm{~d} s}+0.904\right)\left(\frac{\mathrm{d} H}{\mathrm{~d} s}\right)^{0.4}=0.127 \\
\frac{\mathrm{d} H}{\mathrm{~d} s}=0.0072=3 \mathrm{~m} / 400 \mathrm{~m}
\end{gathered}
$$

in summer:

$$
\begin{gathered}
\left(\frac{\mathrm{d} H}{\mathrm{~d} s}+0.004\right)\left(\frac{\mathrm{d} H}{\mathrm{~d} s}\right)^{0.4}=0.064, \\
\frac{\mathrm{d} H}{\mathrm{~d} s}=0.138=55 \mathrm{~m} / 400 \mathrm{~m} .
\end{gathered}
$$

It appears that the seasonal variations of our new term $-(a \theta / Q)(\mathrm{d} Q / \mathrm{d} s)$ are the main controlling factor of $\mathrm{d} H / \mathrm{d} s$. The grade line of a subglacial flooded conduit with reverse slope should be almost horizontal in winter, when heat is mainly afforded by ground water, and more or less parallel to the glacier surface in summer, when heat comes mainly from the Newtonian energy of running water.

Further up-stream, $\sin \beta$ vanishes, and then becomes positive. Consequently, the slope of the grade line is less, the grade line meets the bedrock, and the conduit again becomes not flooded.

For the rough estimation above, it has been assumed that a subglacial waterway exists in the middle of the valley. This should be the case up-stream from the overdeepening, where the waterway is not flooded, and glacier sliding carries this central subglacial waterway downstream. Now, in our opinion, this situation is unstable, and water leaves the waterway. This is a consequence of the many interconnections, most of them without significant flow, but which suffice to give the neighbouring waterways the same hydraulic head $H$.

(a) Let us consider two parallel flooded conduits: $\sin \beta$ is the same for both, and also $H$ because of the interconnections. For a given $s$, let $Z_{1}$ and $Z_{2}$ be the corresponding altitudes $Z_{\mathrm{k}}$. The glacier surface having more or less the same altitude $H_{\mathrm{i}}$ on both waterways:

$$
\Delta H_{2}-\Delta H_{1}=\left(1-\frac{\rho_{\mathrm{i}}}{\rho_{\mathrm{w}}}\right)\left(Z_{2}-Z_{1}\right) .
$$

According to Equation (20) the ratio of the corresponding discharges, in the steady state, is

$$
Q_{1} / Q_{2}=\left(\Delta H_{1} / \Delta H_{2}\right)^{15} \text {. }
$$

Thus the highest waterway carries almost all the water.

(b) Let us consider, going down-stream, a branching into two conduits of slopes $\beta_{1}$ and $\beta_{2}$. According to Equation (20) we have, $C$ being a positive quantity,

$$
Q_{1}^{1 / 5}\left(\sin \beta_{1}+C\right)=Q_{2}^{1 / 5}\left(\sin \beta_{2}+C\right) \text {. }
$$

Thus the discharge is bigger in the conduit with less normal slope, or with larger reverse slope.

It follows that in an overdeepening most water should eventually flow along the banks as gradient conduits. A "gradient conduit", as defined by Röthlisberger, is the highest possible flooded conduit, the one which is entirely at atmospheric pressure. Since ground water springs from lateral moraines, affording heat, gradient conduits should be lower than calculated by this 
author. At a first approximation, they should run at the altitude of the lowest point of the Riegel which produces the overdeepening.

Röthlisberger is not so categorical in his conclusions because he says any transverse connection linking two waterways acts as a valve: it enlarges when flow is in the downward direction, narrows when it is upwards. This would be true in the steady state, if water was always flowing along such connections. But, as soon as the hydraulic heads are equalized, there is no longer any flow in a connection; it transmits pressure only.

\section{CONSEQUENCES FOR GLACIER SLIDING THEORY}

It has been shown that the incredibly large closure rates by plasticity introduced by Röthlisberger can be explained. The main point missed in former theories is the large amount of heat which may be afforded by ground water.

Nevertheless, even when ground water is ignored, for not too thick glaciers our conclusions differ widely from his. No important waterways should exist in overdeepened areas. Everywhere else, apart from the beginning of the melting season, subglacial waterways at atmospheric pressure should be a common situation.

This conclusion would make it difficult to explain the fast sliding of glaciers, which demands ice-bedrock separation, when the glacier is moderately thick and there is no overdeepening. It becomes necessary to introduce a non-negligible head loss between the subglacial cavities and the main waterway, contrary to the author's previous opinion. Field work and precise calculations are needed to see whether this is really a problem.

On the other hand, the fact that during most of the time subglacial pressures have constant values removes an objection which could be made to author's sliding theory (Lliboutry, 1979). According to this theory, when sliding is important, the bottom drag is more or less

$$
\tau_{\mathrm{b}}=f \rho_{\mathrm{w}} g\left(p_{\mathrm{i}}-p\right)
$$

where $\rho_{\mathrm{w}} g p_{\mathrm{i}}$ is the mean pressure of ice against bedrock and $\rho_{\mathrm{w}} g p$ the hydrostatic pressure in leeward cavities. Until 1979 the author maintained that there was no significant head loss between subglacial cavities and the main waterway. Then $p$ would have strong diurnal and weekly fluctuations, not only seasonal ones, as would the drag and the sliding velocity. Now, in the case of Mer de Glace at least, a fast-sliding valley glacier, diurnal fluctuations of the velocity do not exist (Reynaud, 1975).

Field work at glacier d'Argentière and the present theory lead to the following different model.

Since bottom ice has a small permeability, $\rho_{\mathrm{w}} g p$, on the scale of days, is the pore pressure of water in bottom ice. It equals the pressure in the subglacial waterway plus a substantial moreor-less constant head loss. Most of the year the subglacial waterway is at atmospheric pressure or, when it exists in an overdeepened area, at almost the same pressure as if there were no glacier and a lake existed in this overdeepening. It is only during the floods of the melting season that subglacial waterways are under much stronger pressures. Then the head losses lower or reverse sign, the pore pressure increases, the drag diminishes, and sliding velocity increases.

Before going further, we need better estimates of ground-water inputs and measurements of its temperature. 


\section{REFERENCES}

Berner, W., and others. [1978.] Dynamic glacier flow model and the production of internal meltwater, by W. Berner, B. Stauffer, and H. Oeschger. Zeitschrift für Gletscherkunde und Glazialgeologie, Bd. 13, Ht. 1-2, 1977, p. 209-17.

Bezinge, A. Unpublished. Sites sous-glaciaires des Alpes. [Paper presented at the meeting Glaces Tempérées. Colloque de la Section des Alpes occidentales de l'International Glaciological Society, Chamonix, 27-29 October 1972.]

Duval, P. 1977[a]. Lois du fluage transitoire ou permanent de la glace polycristalline pour divers états de contrainte. Annales de Géophysique, Tom. 32, No. 4, 1976, p. 335-50.

Duval, P. 1977|b]. The role of the water content on the creep rate of polycrystalline ice. [Union Géodesique et Geophysique Internationale. Association Internationale des Sciences Hydrologiques. Commission des Neiges et Glaces.] Symposium. Isotopes et impuretes dans les neiges et glaces. Actes du colloque de Grenoble. août/septembre 1975, p. 29-33. (IAHS-AISH Publication No. 118.)

Fontes, J. C., and others. 1979. Hydrologie isotopique du Massif du Mont-Blanc, par J. C. Fontes, G. C. Bortolami, et G. M. Zuppi. (In Isotope hydrology 1978. Proceedings of an international symposium on isotope hydrology jointly organized by the International Atomic Energy Agency and the United Nations Educational, Scientific and Cultural Organization and held in Neuherberg, 19-23 June 1978. Vienna, International Atomic Energy Agency, p. $411-40$.)

Glen, J. W. 1954. The stability of ice-dammed lakes and other water-filled holes in glaciers. Journal of Glaciology, Vol. 2, No. 15, p. 316-18.

Haefeli, R. 1963. Observations in ice tunnels and the flow law of ice. (In Kingery, W. D., ed. Ice and snow; properties, processes, and applications: proceedings of a conference held at the Massachusetts Institute of Technology, February 12-16, 1962. Cambridge, Mass., M.I.T. Press, p. 162-86.)

Hantz, D., and Lliboutry, L. A. 1983. Waterways, ice permeability at depth, and water pressures at glacier d'Argentière, French Alps. Journal of Glaciology, Vol. 29, No. 102, p. 227-39.

Harrison, W. D. 1972. Temperature of a temperate glacier. Journal of Glaciology, Vol. 11, No. 61, p. 15-29.

Lliboutry, L. A. 1971. Permeability, brine content, and temperature of temperate ice. Journal of Glaciology, Vol. 10, No. 58 , p. $15-29$.

Lliboutry, L. A. 1979. Local friction laws for glaciers: a critical review and new openings. Journal of Glaciology, Vol. 23, No. 89, p. 67-95.

Mathews, W. H. 1973. Record of two jökulhlaups. Union Géodésique et Géophysique Internationale. Association Internationale d'Hydrologie Scientifique. Commission de Neiges et Glaces. Symposium on the Hydrology of Glaciers, Cambridge, 7-13 September 1969, p. 99-110. (Publication No. 95 de l'Association Internationale d'Hydrologie Scientifique.)

Nye, J. F. 1976. Water flow in glaciers: jökulhlaups, tunnels, and veins. Journal of Glaciology, Vol. 17 , No. 76. p. $181-207$.

Reynaud, L. 1975. Mouvements du glacier en surface sur une courte échelle de temps. Bulletin des Sciences Hydrologiques, Vol. 20, No. 3, p. 329-39.

Röthlisberger, H. 1972. Water pressure in intra- and subglacial channels. Journal of Glaciology, Vol. 11 , No. 62. p. 177-203.

Spring, U., and Hutter, K. 1981. Numerical studies of jökulhlaups. Cold Regions Science and Technology, Vol. 4, No. 3, p. 227-44.

Stenborg, T. 1973. Some viewpoints on the internal drainage of glaciers. Union Géodesique et Géophysique Internationale. Association Internationale d'Hydrologie Scientifique. Commission de Neiges et Glaces. Symposium on the Hydrology of Glaciers, Cambridge, 7-13 September 1969, p. 117-29. (Publication No. 95 de l'Association Internationale d'Hydrologie Scientifique.)

Weertman, J. 1973. Can a water-filled crevasse reach the bottom surface of a glacier? Union Géodesique et Géophysique Internationale. Association Internationale d'Hydrologie Scientifique. Commision de Neiges et Glaces. Symposium on the Hydrology of Glaciers, Cambridge, 7-13 September 1969, p. 139-45. (Publication No. 95 de l'Association Internationale d'Hydrologie Scientifique.) 